\title{
Effects of termal treatment on the physical properties of Buchenavia sp. (branquilho) wood
}

Efeitos do tratamento térmico nas propriedades físicas da madeira de Buchenavia sp. (branquilho)

\begin{abstract}
Laysa Teles Vollbrecht
Adriano Reis Prazeres Mascarenhas

Rafael Rodolfo de Melo

Maúcha Fernanda de Mota Lima

Ricardo Pereira Soteil

Alexandre Santos Pimenta

\section{Abstract}

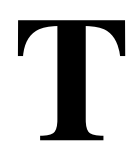

his work aimed to evaluate the effect of heat treatment on the physical properties of wood from Buchenavia sp. The heat treatments were carried out at temperatures of $180{ }^{\circ} \mathrm{C}$ and $200^{\circ} \mathrm{C}$ for $2 \mathrm{~h}$. Apparent density $(\mathrm{AD})$, basic density $(\mathrm{BD})$, porosity $(\Phi)$, mass loss, longitudinal (LS), radial (RS), tangential (TS) and volumetric (VS) shrinkages and anisotropic factor (AF) were determined. The lowest values of basic density $\left(0.67 \mathrm{~g} \mathrm{~cm}^{-3}\right)$, apparent density $\left(0.77 \mathrm{~g} \mathrm{~cm}^{-3}\right)$, and porosity $(43.3 \%)$ were observed for the wood treated at a temperature of $200{ }^{\circ} \mathrm{C}$. Mass losses increased with increasing temperature and the highest values were observed under the condition of $200{ }^{\circ} \mathrm{C}$ (9.3\%). The LS and AF was not affected by heat treatments. The mean values for

1'Laysa Teles Vollbrecht ${ }^{1}$ Universidade Federal de Rondônia Rolim de Moura - RO - Brasil

${ }^{2}$ Adriano Reis Prazeres Mascarenhas 2Universidade Federal de Rondônia Rolim de Moura - RO - Brasil

${ }^{3}$ Rafael Rodolfo de Melo ${ }^{3}$ Universidade Federal Rural do SemiÁrido Mossoró - RN - Brasil

${ }^{4}$ Maúcha Fernanda de Mota Lima ${ }^{4}$ Universidade Federal de Mato Grosso Cuiabá - MT - Brasil

${ }^{5}$ Ricardo Pereira Soteil ${ }^{5}$ Universidade Federal de Rondônia Rolim de Moura - RO - Brasil

${ }^{6}$ Alexandre Santos Pimenta ${ }^{6}$ Universidade Federal do Rio Grande do Macaíba - RN - Brasil RS $(3.1 \%)$, TS $(5.1 \%)$, and VS $(9.1 \%)$ were reduced after the performance of heat treatments at temperatures of $180{ }^{\circ} \mathrm{C}$ and $200^{\circ} \mathrm{C}$, which did not differ from each other. The thermal treatments were able to reduce the dimensional instability of Buchenavia sp. Thermal treatments enhance the use of less prestigious Amazonian woods in the civil construction market.

Keywords: Hygroscopicity of wood. Tropical wood. Wood density. Wood shrinkage.

\section{Resumo}

Objetivou-se avaliar o efeito do tratamento térmico nas propriedades físicas da madeira de Buchenavia sp. Os tratamentos térmicos foram feitos em temperaturas de $180{ }^{\circ} \mathrm{C}$ e $200{ }^{\circ} \mathrm{C}$ durante $2 \mathrm{~h}$. Avaliou-se a densidade aparente $(A D)$, densidade básica $(B D)$, porosidade $(\Phi)$, perda de massa, contração longitudinal (LS), radial (RS), tangencial (TS) e volumétrica (VS) e fator anisotrópico $(A F)$. Os menores valores de densidade básica $\left(0,67 \mathrm{~g} \mathrm{~cm}^{-}\right.$ $\left.{ }^{3}\right)$, densidade aparente $\left(0,77 \mathrm{~g} \mathrm{~cm}^{-3}\right)$ e porosidade $(43,3 \%)$ foram observados para a madeira tratada em temperatura de $200{ }^{\circ} \mathrm{C}$. As perdas de massa foram crescentes com o aumento da temperatura e os maiores valores foram observados na condição de $200{ }^{\circ} \mathrm{C}(9,3 \%)$. A LS e o AF não foram afetados pelos tratamentos térmicos. Os valores médios para RS $(3,1 \%), T S(5,1 \%) e$ VS $(9,1 \%)$ foram reduzidos após a realização dos tratamentos térmicos nas temperaturas de $180{ }^{\circ} \mathrm{C}$ e $200{ }^{\circ} \mathrm{C}$, que não diferiram entre si. Os tratamentos térmicos foram capazes de diminuir a instabilidade dimensional da madeira de Buchenavia sp. Os tratamentos térmicos potencializam o uso de madeiras da Amazônia de menor prestígio no mercado no contexto da construção civil.
\end{abstract}

Recebido em 02/07/20 Aceito em 07/09/21
Palavras-chave: Densidade da madeira. Higroscopicidade da madeira. Madeira tropical. Retratibilidade da madeira. 


\section{Introduction}

Wood is by far one of the materials more used by mankind from pre-historical times to the present day, mainly due to its excellent and versatile technological properties, which permit its application in several forms, such as: civil construction, flooring, furniture uses, watercraft, musical instruments, pulp and paper, source of chemicals and firewood, among other uses (FIGUEROA; MORAES, 2009; RAMAGE et al., 2017). The anisotropic character of wood can raise some problems along variations in the moisture content, for instance, reflected negatively as twisting, cracking, splitting, bowing and also changes in shape and size of sawn pieces from the green to dry condition (SARGENT, 2019; MASCARENHAS; GHILARDI; MELO, 2020).

Therefore, in order to prevent or even eliminate the occurrence of defects during wood processing and drying, and also to avoid decay during its utilization, some techniques have been successfully developed with more or less efficiency on reducing the hygroscopicity of wood and the gain and loss of moisture with ambient conditions.

Among the processes employed on wood modification, the thermal treatment stands out since it can improve wood properties such as dimensional stability, water resistance and also durability, especially without addition of any type of chemicals (HILL, 2007; JIROUŠ-RAJKOVIĆ; MIKLEČIĆ, 2019). According to Silva et al. (2015), the benefits of heat treatments are majorly associated to the degradation of hemicelluloses, which are responsible for a significant role on sorption and desorption of water in the wood cell wall. This way, temperatures for heat treatment are usually in the range of 160 a $260{ }^{\circ} \mathrm{C}$ and the higher the temperature is greater will be the losses in mechanical strength of the wood, what can sometimes severely restrain its use for structural applications (ESTEVES; PEREIRA, 2009; SILVA et al., 2015; PERCIN; PEKER; ATILGAN, 2016; SANDBERG; KUTNAR, 2016).

The contributions of heat-treated wood are also decisive to a low-carbon economy as presented by kutnar, Sandberg and Haller (2015), who highlighted that new modification processes of the material, such as thermal treatment, are important strategies to offer to the wood some technological applications without changing its eco-friendly characteristics and additionally broadening its fields of use. Other characteristics to be considered when thermal treatment is applied to the wood is the improvement of the color of the heartwood in lighter-colored woods, turning them into a higher-value-added species (FREITAS; GONÇALVEZ; DEL MENEZZI, 2016). However, most of the information on the application of thermal treatment to improve wood quality and value is available for non-Brazilian species.

Within the rationale exposed above, there is a lack in the literature of research works dealing with the use of thermal treatment to improve the quality of low-rated Amazonian wood species. There are so many useful and noble species in the Amazon rainforest that several of them, although having medium or high density and good characteristics for woodworking, only because of one or another physical property such as dimensional stability, for example, or yet for not having good aesthetical characteristics, are left behind at the time of harvesting in sustainable management plans. Within this context, the species Buchenavia sp. (Combretaceae), commonly known as "branquilho" (INSTITUTO BRASILEIRO..., 2021; RONDÔNIA, 2021) may be included. Its wood does not have any consolidated market compared to other Amazonian species, despite presenting acceptable physical-mechanical properties to be employed in civil construction, tools handles, and veneering (REIS et al., 2019; INSTITUTO DE PESQUISAS..., 2021). The main limitation of wood of this species is its dimensional instability, which promotes the occurrence of warping and cracking during drying and its use in external applications Moreover, its light color, within the Brazilian market, is associated to low quality woods. Because of this, is does not have prestige for more noble uses as wood sheeting and furniture, the interior finishing of homes, and frames and sheets for coating engineered wood panels."

The presented context meets the aspects associated with the technology of the built environment, such as sustainability, the need for technological development in civil construction, and rationalization of costs. The understanding of techniques, such as thermo-rectification, to enhance the use of little-known Amazonian woods, whose aesthetic and technological characteristics are undesirable for the market, can contribute to reducethe overexploitation of species and reduce costs with wood, allowing its application in buildings for uses for which it would not be considered previously. Thus, the objective of the present work was to assess the effects of thermal treatment on the physical properties of the Buchenavia sp. wood. 


\section{Material and methods \\ Obtaining the samples}

In order to obtain the test specimens, in a sawmill located at the municipality of Rolim de Moura (Rondônia State, Brazil), two $0.6 \mathrm{~m}$ diameter logs were quarter-sawn by using a band saw and from each log, three radial boards with final dimensions of $2 \mathrm{~m}$ length $\times 0.2 \mathrm{~m}$ width $\mathrm{x} 0.025 \mathrm{~m}$ thickness were obtained. Next, the boards underwent resawing to remove sapwood and pith, and as well wood defects such as knots, cracks, and grain slopes.

From each board, 60 test specimens with final dimensions of $0.1 \mathrm{~m}$ length $\mathrm{x} 0.025 \mathrm{~m}$ width $\mathrm{x} 0.025 \mathrm{~m}$ thickness were cut, according to procedures described in the standard D143-14 (AMERICAN..., 2014). The test specimens were accurately cut to expose the longitudinal, tangential and radial wood sections.

\section{Conducting thermal treatment}

The samples were conditioned at $20{ }^{\circ} \mathrm{C}$ and $65 \%$ relative humidity until reaching the hygroscopic moisture content $(\sim 12 \%)$. This initial condition was established before the heat treatment. After, the test specimens were randomly divided into three groups. Two of them were thermally treated at $180{ }^{\circ} \mathrm{C}(\mathrm{T} 1)$ and $200{ }^{\circ} \mathrm{C}$ (T2) for $2 \mathrm{~h}$. The third group of wood samples was maintained untreated and used as a reference. Before starting the thermal treatment, all test specimens were oven-dried for $24 \mathrm{~h}$ at $105 \pm 2{ }^{\circ} \mathrm{C}$. At this time, the dry mass was measured to calculate the mass loss after thermal treatment.

Treatments T1 and T2 were applied to the test specimens right after the oven-drying. To reach the final temperatures of the respective thermal treatments, a heating rate of $20^{\circ} \mathrm{C} / 5 \mathrm{~min}$ was carried out. After $2 \mathrm{~h}$ in the respective final temperatures, the oven was switched off and left to cool until reaching $30{ }^{\circ} \mathrm{C}$. After this step, the thermal-treated test specimens were taken to conditioning until reaching constant weight. A microprocessor-controlled oven with electric heating was employed both for drying and heat treatment. All tests were carried out without any gas injection, relying only on atmospheric air inside the equipment, according to the methodology reported by Delucis et al. (2014) and Modes, Santini and Haselein (2017).

\section{Calculation of analyzed variables}

The basic density of the wood was determined by following the procedures described in the standard NBR 7190 (ABNT, 1997), and is defined as the ratio between the wood dry mass and the saturated volume of the sample. Saturated volume was determined from the radial, tangential, and longitudinal linear measures. For all samples, the basic density was determined, and for those submitted to thermal treatment that property was evaluated after the experimental treatment.

Following the aforementioned standard, the apparent density of the wood was obtained by the ratio between the mass and the volume of the wood specimen with moisture content equal to $12 \%$. To reach this target moisture content, the wood specimens were conditioned at $65 \%$ of relative humidity and temperature of 22 ${ }^{\circ} \mathrm{C}$ in a climatic chamber until reaching equilibrium. The dry masses of the samples were recorded before and after the heat treatments to allow the calculation of the mass loss caused by the heat treatment, as pointed out above.

For radial and tangential faces, in each face, three measures were taken, one in the center and two others in each far end of the specimen with a precision of $0.01 \mathrm{~mm}$, obtaining, this way, the average measures for each face. For the longitudinal face, the average measure of the four faces along the length direction was also taken with a precision of $0.01 \mathrm{~mm}$.

\section{Statistical analysis}

The experiment was set as in an entirely randomized design with three treatments, two temperatures of thermal treatment, and a control witness treatment, respectively, with 60 replicates (test specimens) per experimental treatment. Experimental data were submitted to analysis of variance and when the significant statistical difference was detected, the Scott-Knott test at $95 \%$ of probability was applied. 


\section{Results and discussion}

As experimentally observed, there were no statistical differences between the values of basic and apparent densities and, also, between the porosity for the wood treated at $180{ }^{\circ} \mathrm{C}$ and the control treatment (Table 1). However, the standard deviation for the porosity of the thermally-treated wood was slightly higher when compared to the control.

As pointed out by Percin, Peker and Atilgan (2016), when the wood is heated at a high temperature, it becomes more brittle and its mechanical strength decreases depending on the level and duration of the thermal treatment which is followed by a concomitant decrease in the wood density. So, more likely it occurred in the assessed material, despite no differences in density was observed after the thermal treatment, even though the heat promotes degradation of the wood cell leaving it susceptible to mechanical fatigue (FIGUEROA; MORAES, 2009).

In Table 2, the experimental results for wood mass loss were brought about by the thermal treatment. As observed, there was no statistical difference of mass loss for the wood treated at $180{ }^{\circ} \mathrm{C}$ compared to the control. Regarding the mass loss, Delucis et al. (2014) discussed that usually, temperatures up to $180{ }^{\circ} \mathrm{C}$ are not enough to promote significant mass losses and as well volume decrease of the wood as determined in the present work.

On the other hand, thermal treatment at $200{ }^{\circ} \mathrm{C}$ resulted in a concomitant decrease in basic and apparent densities, porosity and mass loss. Within this context, Poubel et al. (2013) and Cademartori et al. (2015) reported that such a pattern of decrease in these physical properties of the wood is mainly associated with the degradation of the hemicelluloses and extractives, which is followed by a significant decrease in the wood hygroscopicity.

Those components are the most sensitive to temperature and thermal degradation and their both structural and chemical modification are irreversible since the hydroxyl groups are removed by volatilization, and this is the reason why the wood hygroscopicity decreases (BORREGA; KÄRENLAMPI, 2008). Moreover, as temperatures of thermal treatment rise higher is the mass loss, as found by Conte et al. (2014) who worked with Pinus elliottii wood and determined a mass loss of $6.67 \%$ at $210{ }^{\circ} \mathrm{C}$ of temperature. The mass losses observed for these species were 4.5 times when compared to their original wood.

As shown in Table 3, the longitudinal shrinkage was not significantly influenced by thermal treatment. Such sort of result is expected since in the longitudinal direction the dimensional variations are negligible around 0.1 and $0.3 \%$, depending on the type of wood, basic density, and either amount and type of extractives.

As observed, a reduction in the radial and tangential shrinkage occurred when compared to the control. Korkut and Guller (2008) pointed out that thermal treatment brings about a decrease in the water sorption capacity of the wood cell walls as a result of the decrease in the number of hydroxyl groups and consequently both radial and tangential shrinkage decrease as well.

Table 1 - Means of basic (BD) and apparent (AD) densities and porosity ( $\Phi$ ) for the of wood Buchenavia sp. (branquilho) before and after thermal treatment at $180{ }^{\circ} \mathrm{C}$ and $200{ }^{\circ} \mathrm{C}$

\begin{tabular}{c|c|c|c}
\hline Treatments & $\begin{array}{c}\mathbf{B D} \\
\left(\mathbf{g ~ c m}^{-\mathbf{3}}\right)\end{array}$ & $\begin{array}{c}\mathbf{A D} \\
\left(\mathbf{g ~ c m}^{-3}\right)\end{array}$ & $\begin{array}{c}\boldsymbol{\Phi} \\
(\boldsymbol{\%})\end{array}$ \\
\hline Control & $0.70( \pm 0.04) \mathrm{a}$ & $0.82( \pm 0.05) \mathrm{a}$ & $45.26( \pm 2.84) \mathrm{a}$ \\
$180{ }^{\circ} \mathrm{C}$ & $0.72( \pm 0.05) \mathrm{a}$ & $0.83( \pm 0.06) \mathrm{a}$ & $47.00( \pm 3.23) \mathrm{a}$ \\
$200{ }^{\circ} \mathrm{C}$ & $0.67( \pm 0.05) \mathrm{b}$ & $0.77( \pm 0.06) \mathrm{b}$ & $43.31( \pm 3.24) \mathrm{b}$ \\
\hline
\end{tabular}

Note: numbers between brackets are standard deviations; and means followed by different letters are statistically dissimilar by the Scott-Knott test at $95 \%$ of probability.

Table 2 - Means of mass loss for the of wood Buchenavia sp. (branquilho) before and after thermal treatment at $180{ }^{\circ} \mathrm{C}$ and $200{ }^{\circ} \mathrm{C}$

\begin{tabular}{c|c}
\hline Treatments & Mass Loss (\%) \\
\hline Control & $0.0 \mathrm{a}$ \\
$180^{\circ} \mathrm{C}$ & $2.56( \pm 0.99) \mathrm{a}$ \\
$200^{\circ} \mathrm{C}$ & $9.32( \pm 3.95) \mathrm{b}$ \\
\hline
\end{tabular}

Note: numbers between brackets are standard deviations; and means followed by different letters are statistically dissimilar by the Scott-Knott test at $95 \%$ of probability. 
Table 3 - Means of longitudinal (LS), radial (RS), and tangential shrinkage (TS) Means of mass loss for the of wood Buchenavia sp. (branquilho) before and after thermal treatment at 180 and $200{ }^{\circ} \mathrm{C}$ before and after thermal treatment at $180{ }^{\circ} \mathrm{C}$ and $200{ }^{\circ} \mathrm{C}$

\begin{tabular}{c|c|c|c}
\hline \multirow{2}{*}{ Treatments } & LS & RS & TS \\
\cline { 2 - 4 } & \multicolumn{3}{|c}{$(\boldsymbol{\%})$} \\
\hline Control & $0.28( \pm 0.25) \mathrm{a}$ & $4.60( \pm 1.76) \mathrm{a}$ & $7.54( \pm 1.68) \mathrm{a}$ \\
$180^{\circ} \mathrm{C}$ & $0.22( \pm 0.16) \mathrm{a}$ & $3.30( \pm 1.04) \mathrm{b}$ & $5.59( \pm 1.50) \mathrm{b}$ \\
$200^{\circ} \mathrm{C}$ & $0.25( \pm 0.14) \mathrm{a}$ & $2.90( \pm 0.95) \mathrm{b}$ & $4.61( \pm 2.37) \mathrm{b}$ \\
\hline
\end{tabular}

Note: numbers between brackets are standard deviations; and means followed by different letters are statistically dissimilar by the Scott-Knott test at $95 \%$ of probability.

Usually, the tangential shrinkage is the most affected property when the wood is submitted to thermal treatment and such behavior was observed in the present work where the tangential wood movement decreased in $71 \%$ and $63 \%$ at temperatures of $180{ }^{\circ} \mathrm{C}$ and $200{ }^{\circ} \mathrm{C}$, respectively, when compared to the original wood. The wood radial is commonly twice as less than the tangential one. In this research study, thermal treatment was able to reduce the radial movement by about $74 \%$ and $61 \%$ for the temperatures of $180{ }^{\circ} \mathrm{C}$ and $200{ }^{\circ} \mathrm{C}$.

Since, for the pristine wood of the forest species assessed here, the mean radial and tangential shrinkage are higher than $4 \%$ and $7 \%$, respectively, the stability can be classified as medium. After thermal treatment application, the values were reduced to the range of $2.90 \%$ to $3.30 \%$ for the radial movement and $4.61 \%$ to $5.59 \%$ for the tangential shrinkage, which led the stability of the wood to be classified as high dimensional (RUFFINATTO; CRIVELLARO; WIEDENHOEFT, 2015).

Bearing in mind the patterns discussed above, for a practical application, it is preferable to employ the thermal treatment at $180^{\circ} \mathrm{C}$ because, besides improving dimensional stability of the Buchenavia sp. wood, it also caused a smaller mass loss and no alteration on the wood density. On the other hand, as shown in Figure 1, the thermal treatment at $200{ }^{\circ} \mathrm{C}$ promoted a higher darkening of the wood. Such a darker color can make some sorts of wood more attractive to the final consumers, depending on the market preferences, as pointed out by Freitas, Gonçalvez and Del Menezzi (2016).

In Table 4, the results obtained for the volumetric shrinkage and the anisotropy factor are presented. The values of volumetric shrinkage are statistically different when compared to the control with the decrease in this parameter. However, there were no differences between the two thermal treatments. Once again, as mentioned before concerning the linear shrinkages, the thermal treatment at $180{ }^{\circ} \mathrm{C}$ is recommended since it brings about low mass loss.

Additionally, as volumetric shrinkage (VS) is an unwelcome characteristic for many kinds of wood uses, the results accomplished by applying the thermal treatments on the Buchenavia sp. wood turned it from medium dimensional stability with VS of $13.81 \%$ in the control to high stability with $8.32 \%$ and $9.81 \%$ of VS for thermal treatment at $180{ }^{\circ} \mathrm{C}$ and $200{ }^{\circ} \mathrm{C}$, respectively, results explained by the significant reduction in the combined tangential and radial shrinkages. Nevertheless, no statistical differences were observed in the anisotropy factor (AF) between the control and the thermal treatments, which probably can be due to a proportional decrease in both tangential and radial shrinkages, whose ratio was kept constant.

This way, by comparing the values, the AFs can be considered normal-wood-like since they are in the range of 1.50 and 2.00. As discussed by Melo et al. (2013) and Mascarenhas et al. (2021a, 2021b), the AF cannot be solely considered as a parameter to define the dimensional stability of wood, because it is not exactly a limiting parameter for its use, since by using proper conditions of drying and woodworking woods with high AF can be normally used without any problems.

Within a general context, the experimental results found in this work showed that $2 \mathrm{~h}$ duration thermal treatments at $180{ }^{\circ} \mathrm{C}$ and $200{ }^{\circ} \mathrm{C}$ can satisfactorily increase the dimensional stability of the Buchenavia sp. wood without significant mass losses and alteration on its basic density. The improvement in dimensional stability acquired by thermal treatment enables the wood of the species to be indicated to nobler end uses such as fine furniture, window and door frames, wood sheeting for walls, which typically require more expensive and less widely available woods. 
Figure 1 - Color differences among the of wood Buchenavia sp. (branquilho) of control (a), before and after thermal treatment at $180^{\circ} \mathrm{C}$ (b) and $200{ }^{\circ} \mathrm{C}$ (c)

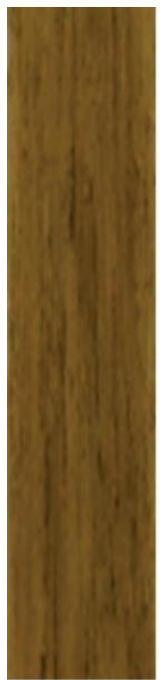

(a)

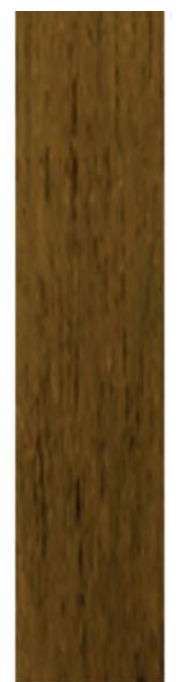

(b)

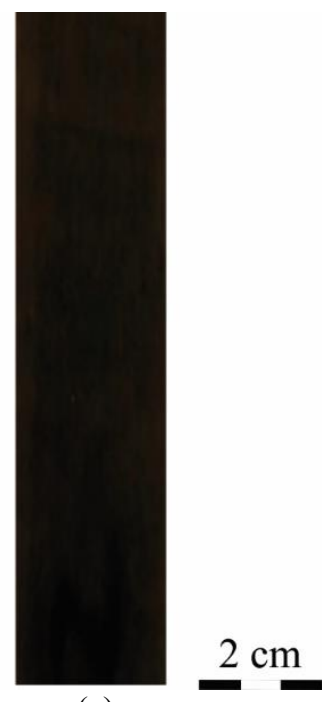

(c)

Table 4 - Means of volumetric shrinkage (VS) and anisotropy factor (AF) for the of wood Buchenavia sp. (branquilho) before and after thermal treatment at $180{ }^{\circ} \mathrm{C}$ and $200{ }^{\circ} \mathrm{C}$

\begin{tabular}{c|c|c}
\hline Treatments & VS (\%) & AF \\
\hline Control & $13.81( \pm 3.55) \mathrm{a}$ & $1.86( \pm 0.78) \mathrm{a}$ \\
$180^{\circ} \mathrm{C}$ & $9.81( \pm 2.23) \mathrm{b}$ & $1.87( \pm 0.87) \mathrm{a}$ \\
$200^{\circ} \mathrm{C}$ & $8.32( \pm 3.24) \mathrm{b}$ & $1.68( \pm 0.85) \mathrm{a}$ \\
\hline
\end{tabular}

Note: numbers between brackets are standard deviations; and means followed by different letters are statistically dissimilar by the Scott-Knott test at $95 \%$ of probability.

As observed, the heat treatment contributed to the increase in the dimensional stability of the Buchenavia sp. wood to ranges similar to those reported for high-dimensional-stability woods, especially the values presented by Pereira (2013) for the radial, tangential, and volumetric shrinkages. Moreoverl, there was a color alteration of the wood becoming darker, which can make it more attractive for uses such as siding or fine finishing. Therefore, woods commonly employed for those uses such as cumaru (Dipteryx odorata) and ipê (Tabebuia impetiginosa) may be substituted by the forest species assessed after thermal treatment in this work. More likely, these new possibilities of use can contribute to decrease the overexploitation of small groups of tropical forest species (REIS et al., 2019; MASCARENHAS et al., 2021c), since now an unconventional species, when properly heat-treated, can present similar characteristics to those traditionally marketed. These aspects are in context with the technology from the built environment, given that they are based on sustainability, the need for technological development in the production of civil construction, and the rationalization of costs.

\section{Conclusions}

Thermal treatments with $2 \mathrm{~h}$ of duration at $180{ }^{\circ} \mathrm{C}$ and $200{ }^{\circ} \mathrm{C}$ increased significantly the dimensional stability of Buchenavia sp. wood with the decrease of basic density and concomitant mass loss as temperature increased. The longitudinal shrinkage was not significantly influenced by thermal treatment. The application of thermal treatment at $180{ }^{\circ} \mathrm{C}$ is recommended when the objective is to obtain improvements in dimensional stability with negligible mass loss and minimum alterations in the basic density.

\section{References}

AMERICAN SOCIETY FOR TESTING AND MATERIALS. D143-14: standard methods testing: small clear specimens of timber. Philadelphia, 2014.

100 Vollbrecht, L. T.; Mascarenhas, A. R. P.; Melo, R. R. de; Lima, M. F. de M.; Soteil, R. P.; Pimenta, A. S. 
ASSOCIAÇÃO BRASILEIRA DE NORMAS TÉCNICAS. NBR 7190: projeto de estruturas de madeira. Rio de Janeiro, 1997.

BORREGA, M.; KÄRENLAMPI, P. P. Mechanical behavior of heat-treated spruce (Picea abies) wood at constant moisture content and ambient humidity. Holz als Roh-und Werkstoff, v. 66, n. 1, p. 63-69, 2008.

CADEMARTORI, P. H. G. D. et al. Effect of thermal treatments on technological properties of wood from two Eucalyptus species. Anais da Academia Brasileira de Ciências, v. 87, n. 1, p. 471-481, 2015.

CONTE, B. et al. Physical and colorimetric properties of Pinus elliottii var. elliottii thermally treated wood. Scientia Forestalis, v. 42, n. 104, p. 555-563, 2014.

DELUCIS, R. A. et al. Physical properties of four thermally treated hardwoods. Floresta e Ambiente, v. 21, n. 1, p. 99-107, 2014.

ESTEVES, B. M.; PEREIRA, H.M. Wood modification by heat treatment: a review. BioResources, v. 4, n. 1, p. 370-404, 2009.

FIGUEROA, M. J. M.; MORAES, P. D. Wood behavior at high temperatures. Ambiente Construído, Porto Alegre, v. 9, n. 4, p. 157-174, out./dez. 2009.

FREITAS, A. S.; GONÇALEZ, J. C.; DEL MENEZZI, C. H. Thermomechanical treatment and the effects on the properties of Simarouba amara (Aubl.). Floresta e Ambiente, v. 23, n. 4, p. 565-572, 2016.

HILL, C. A. Wood modification: chemical, thermal and other processes. Hoboken: John Wiley \& Sons, 2007.

INSTITUTO BRASILEIRO DO MEIO AMBIENTE E DOS RECURSOS NATURAIS RENOVÁVEIS.

Sistema Nacional de Controle da Origem dos Produtos Florestais (Sinaflor): tabela de espécies do Sistaxon. Brasília, 2021. Available: https://www.ibama.gov.br/sinaflor. Access: 26 feb. 2021.

INSTITUTO DE PESQUISAS TECNOLÓGICAS. Informações sobre madeiras. Nome científico: Buchenavia sp. São Paulo, 2021. Available at: https://www.ipt.br/informacoes_madeiras3.php?madeira=76. Access on: 26 fev. 2021.

JIROUŠ-RAJKOVIĆ, V.; MIKLEČIĆ, J. Heat-treated wood as a substrate for coatings, weathering of heattreated wood, and coating performance on heat-treated wood. Advances in Materials Science and Engineering, v. 2019, p. 1-9, 2019.

KORKUT, D. S.; GULLER, B. The effects of heat treatment on physical properties and surface roughness of red-bud maple (Acer trautvetteri Medw.) wood. Bioresource technology, v. 99, n. 8, p. 2846-2851, 2008.

KUTNAR, A.; SANDBERG, D.; HALLER, P. Compressed and moulded wood from processing to products: COST action FP0904 2010-2014: thermo-hydro-mechanical wood behaviour and processing.

Holzforschung, v. 69, n. 7, p. 885-897, 2015.

MASCARENHAS, A. R. P. et al. Characterization of wood from Schizolobium parahyba var. amazonicum Huber $\times$ Ducke trees from a multi-stratified agroforestry system established in the Amazon rainforest.

Agroforestry Systems, v. 95, p. 475-486, 2021a.

MASCARENHAS, A. R. P. et al. Ultrasound to estimate the physical-mechanical properties of tropical wood species grown in an agroforestry system. Holzforschung, ahead of print, p. 1-13, 2021c.

MASCARENHAS, A. R. P. et al. Wood quality of Khaya senegalensis trees from a multi-stratified agroforestry system established in an open ombrophilous forest zone. Wood Material Science and Engineering, p. 1-10, 2021b.

MASCARENHAS, A. R. P.; GHILARDI, D. S.; MELO, R. R. Geotecnologias aplicadas ao zoneamento sazonal da umidade de equilíbrio da madeira em Rondônia, Brasil. Anuário do Instituto de Geociências, v. 43, n. 2, p. 119-127, 2020.

MELO, R. R. et al. Evaluation of physical, chemical, mechanical and surface properties of the Schizolobium amazonicum Veneer. Floresta e Ambiente, v. 20, n. 2, p. 238-249, 2013.

MODES, K. S.; SANTINI, E. J.; HASELEIN, C. R. Effect of heat treatment on mechanical properties of Pinus taeda and Eucalyptus grandis woods. Ciência Florestal, v. 27, n. 1, p. 291-302, 2017.

PERCIN, O.; PEKER, H.; ATILGAN, A. The effect of heat treatment on some physical and mechanical properties of beech (Fagus orientalis Lipsky) wood. Wood Research, v. 61, n. 3, p. 443-456, 2016. 
PEREIRA, A. F. Madeiras Brasileiras. São Paulo: Blucher, 2013.

POUBEL, D. S. et al. Effect of the heat treatment on physical and chemical properties of Pinus caribaea wood. Cerne, v. 19, n. 3, p. 391-398, 2013.

RAMAGE, M. H. et al. The wood from the trees: the use of timber in construction. Renewable and Sustainable Energy Reviews, v. 68, p. 333-359, 2017.

REIS, P. C. M. R. et al. Clustering of Amazon wood species based on physical and mechanical properties. Ciência Florestal, v. 29, n. 1, p. 336-346, 2019.

RONDÔNIA. Pauta Fiscal de mercadorias e produtos (Nome científico de madeiras comercializadas em Rondônia). Instrução Normativa ${ }^{\circ}$ 8/2021/SEFIN-GETRI de 01 de fevereiro de 2021. Porto Velho, 2021.

RUFFINATTO, F.; CRIVELLARO, A.; WIEDENHOEFT, A. C. Review of macroscopic features for hardwood and softwood identification and a proposal for a new character list. IAWA Journal, v. 36, n. 2, p. 208-241, 2015.

SANDBERG, D.; KUTNAR, A. Thermally modified timber: recent developments in Europe and North America. Wood and Fiber Science, v. 48, n. 1, p. 28-39, 2016

SARGENT, R. Evaluating dimensional stability in solid wood: a review of current practice. Journal of Wood Science, v. 65, n. 1, p. 1-11, 2019

SILVA, M. R. et al. Chemical and mechanical properties changes in Corymbia citriodora wood submitted to heat treatment. International Journal of Materials Engineering, v. 5, n. 4, p. 98-104, 2015.

\author{
Laysa Teles Vollbrecht \\ Departamento Acadêmico de Engenharia Florestal | Universidade Federal de Rondônia | Av. Norte Sul, 7300, Nova Morada | Rolim de \\ Moura - RO - Brasil | CEP 76940-000 | Tel.: (69) 3449-3802 | E-mail: laysateles@hotmail.com
}

Adriano Reis Prazeres Mascarenhas

Departamento Acadêmico de Engenharia Florestal | Universidade Federal de Rondônia | E-mail: adriano.mascarenhas@unir.br

Rafael Rodolfo de Melo

Departamento de Ciências Agronômicas e Florestais | Universidade Federal Rural do Semi-Árido | Rua Francisco Mota Bairro, 572 Presidente Costa e Silva | Mossoró - RN - Brasil | CEP 59625-900 | Tel.: (69) 98179-0123 | E-mail: rafael.melo@ufersa.edu.br

Maúcha Fernanda de Mota Lima

Faculdade de Engenharia Florestal | Universidade Federal de Mato Grosso | Rua Fernando Corrêa da Costa, 2367, Boa Esperança | Cuiabá - MT - Brasil | CEP 78068-600 | Tel.: (65) 3615-8632 | E-mail: mauchaf@gmail.com

\title{
Ricardo Pereira Soteil
}

Departamento Acadêmico de Engenharia Florestal | Universidade Federal de Rondônia | E-mail: ricardo.soteli@unir.br

\section{Alexandre Santos Pimenta}

Engenharia Florestal, Escola Agrícola de Jundiaí | Universidade Federal do Rio Grande do Norte | Rodovia RN 160, Km 03 s/n, Distrito de Jundiaí | Macaíba - RN - Brasil | CEP 59280-000 | Tel.: (84) 3342-4800 | E-mail: alexandre.pimenta@ufrn.br

\author{
Ambiente Construído \\ Revista da Associação Nacional de Tecnologia do Ambiente Construído \\ Av. Osvaldo Aranha, $99-3^{\circ}$ andar, Centro \\ Porto Alegre - RS - Brasil \\ CEP $90035-190$ \\ Telefone: +55 (51) 3308-4084 \\ www.seer.ufrgs.br/ambienteconstruido \\ www.scielo.br/ac \\ E-mail: ambienteconstruido@ufrgs.br
}

